\title{
Cells Born in Adult Canary Forebrain are Local Interneurons ${ }^{1}$
}

\author{
JOHN A. PATON, ${ }^{2}$ BARBARA E. O'LOUGHLIN, AND FERNANDO NOTTEBOHM
}

The Rockefeller University, New York, New York 10021

\begin{abstract}
Thymidine autoradiography and retrograde transport of horseradish peroxidase (HRP) were combined to determine the connectivity of neurons born in adult canary forebrain. Adult male and female canaries were pretreated with $\left[{ }^{3} \mathrm{H}\right]$ thymidine to label cells undergoing DNA synthesis prior to mitosis. Thirty or $\mathbf{6 0}$ days later, neurons in a forebrain nucleus, hyperstriatium ventralis, pars caudalis (HVc), were labeled by retrograde transport of HRP injected into the only two nuclei known to receive a projection from HVc: robustus archistriatalis (RA) and area $X$ of lobus parolfactorius. The birds were then killed and brain sections were treated to visualize cells containing HRP; these sections were processed for autoradiography to detect $\left[{ }^{3} \mathrm{H}\right]$ thymidine-labeled cells in the same tissue. More than $9 \%$ of all neurons in HVc were thymidine labeled; but of the almost $20,000 \mathrm{HRP}$-labeled projection neurons examined, fewer than $20(0.1 \%)$ were labeled by the thymidine treatment. Furthermore, the median cell body size for area X-projecting cells was significantly larger than that of thymidine-labeled cells, and the median size of thymidine-labeled cells was significantly larger than that of RA-projecting cells. The simplest interpretation of these results is that the new neurons incorporated into nucleus HVc in adult canary brain are local interneurons, intermediate in size between neurons projecting to RA and area x.
\end{abstract}

Neurogenesis in the adult central nervous system has now been found in a variety of species and brain nuclei (e.g., Altman, 1970; Kaplan and Hinds, 1977; Leonard et al., 1978; Kaplan, 1981; Bayer et al., 1982; Bayer, 1983; Easter, 1983; Kaplan and Bell, 1983, 1984). The addition of new neurons adds an element of functional plasticity to the adult brain. The limits of this plasticity will presumably be set by the types of neurons that can be produced, which is the subject of this report.

A remarkable example of neurogenesis occurs in adult canaries of both sexes, where neurons are added to nucleus hyperstriatum ventralis, pars caudalis ( $\left.H V_{C}\right)$ at a rate of as much as $1.5 \%$ per day (Nottebohm and Goldman, 1982; Goldman and Nottebohm, 1983).

Received February 25, 1985; Revised May 13, 1985;

Accepted May 11, 1985

\footnotetext{
${ }^{1}$ We thank Ms. C. Rubin for typing this manuscript; Mr. C. Pandazis for technical help; and Drs. L. Katz, K. R. Manogue, and G. D. Burd for constructive criticism of various drafts of this paper. This work was supported by National Science Foundation Grant BNS 82-16031 to J. A. P. and National Institutes of Health Grants NS 17991 and 5RO1 MH18343 to F. N

${ }^{2}$ To whom reprint requests should be addressed at The Rockefeller University, 1230 York Avenue, New York, NY 10021.
}

This anatomically discrete, forebrain nucleus is an essential part of the motor pathway which controls the vocal organ in songbirds (Nottebohm et al., 1976). New cells incorporated into HVc in adulthood have been identified as neurons by light and electron microscopy (Goldman and Nottebohm, 1983; Burd and Nottebohm, 1985) and by intracellular recording and injection of an anatomical label (Paton and Nottebohm, 1984). In the latter study all of the new neurons had spiny dendrites and axonal processes that remained within HVC, and some were auditory; however, the sample was necessarily small. In this paper we report that few, if any, of the neurons shown to project outside $\mathrm{HVc}$, i.e., projection neurons, are labeled by systemic injections of $\left[{ }^{3} \mathrm{H}\right]$ thymidine in adulthood. This leads us to conclude that the HVc neurons born in adulthood are predominantly, if not exclusively, local interneurons, that is, cells with axons confined to HVc. Preliminary work leading to the present study has been described in abstract form (Nottebohm and Goldman, 1982).

\section{Materials and Methods}

We used sever male and seven female adult Wasserschlager canaries, Serinus canarius, ages 14 to 21 months, obtained from our breeding colony. Animals were kept on a seasonal day/night light cycle.

Female canaries received implants of testosterone the day before thymtdine treatment began. Silastic tubing (Dow Corning; inner diameter, 0.030 inches, outer diameter, 0.065 inches) containing $5 \mathrm{~mm}$ of packed testosterone and sealed with Silastic adhesive was placed subcutaneously above the pectoral muscle. Such implants do not affect the proportion of neurons labeled by $\left[{ }^{3} \mathrm{H}\right]$ thymidine (Goldman and Nottebohm, 1983), but do induce male-like circulating levels of hormone (Luine et al., 1980), the production of male-like song, and an increase in the size of vocal control nuclei including $\mathrm{HVC}$ and robustus archistriatalis (RA) (Nottebohm, 1980). We speculated that if new HVc neurons ever formed connections outside $H V_{c}$, then the time of testosterone treatment, with the ensuing anatomical and behavioral changes, could be particularly favorable for detecting such projections. Turthermore, as the vocal control nuclei expand, HVc's anatomical boundaries become easier to delineate and RA presents a larger target for horseradish peroxidase (HRP) injection.

Both males and females received intramuscular injections of $50 \mu \mathrm{Ci}$ of $\left[{ }^{3} \mathrm{H}\right]$ thymidine in $50 \mu \mathrm{l}$ of sterile water $(\sim 2.5 \mu \mathrm{Ci} / \mathrm{gm})$ of body weight, specific activity of $6.7 \mathrm{Ci} / \mathrm{mmol}$; New England Nuclear) every $12 \mathrm{hr}$ for 14 days. This treatment labeis the nuclei of cells undergoing DNA synthesis at the time of treatment and. thus, can be used as a marker of cellular replication (Sidman et al., 1959; Fujita, 1966; Sidman, 1970; Korr, 1980). In the experiments described here, $\left[{ }^{3} \mathrm{H}\right]$ thymidine was administered during the months of June 1983 to February 1984.

Either 30 or 60 days after the last $\left[{ }^{3} \mathrm{H}\right]$ thymidine injection, HRP was placed in either RA or area $X$ to retrogradely label HVc's only known projection neurons (Nottebohm et al., 1976, 1982). Birds were anesthetized with Chloropent (Fort Dodge Laboratories) and held in a stereotaxic apparatus. The brain was exposed over the injection site. Area $X$ was located strictly by stereotaxic coordinates (Stokes et al., 1974), whereas, RA was located by microstimulating with an extracellular microelectrode while recording from the syringeal nerve (Paton and Manogue, 1982). Micropipettes with a tip diameter of 20 to $30 \mu \mathrm{m}$ were filled with an HRP solution ( $25 \% \mathrm{HRP}$, Sigma 
type $\mathrm{VI}$, in $0.05 \mathrm{M}$ Tris, $\mathrm{pH} \mathrm{7.6)}$ and advanced with a microdrive to the injection site. HRP was deposited by passing 3 to $5 \mu \mathrm{A}$ of current for 15 to $25 \mathrm{~min}$. The electrode was then withdrawn, the wound was closed, and the animals were allowed to recover for 2 or 3 days

To prepare brains for histology, birds were deeply anesthetized with an overdose of Chloropent and perfused with saline followed by fixative solution (1.25\% glutaraldehyde, $1 \%$ paraformaldehyde in $0.1 \mathrm{M}$ phosphate buffer, $\mathrm{pH}$ 7.4). The brain was removed from the skull, left in fixative solution overnight at $4^{\circ} \mathrm{C}$, and then cut into $100-\mu \mathrm{m}$ transverse slices on a Vibratome. These slices were incubated with diaminobernzidine (DAB) and hydrogen peroxide to visualize HRP-containing cells (Malmgren and Olsson, 1978). Injection sites were located in slices counterstained with cresyl violet. The remaining slices were cleared in glycerine and examined under a microscope. Slices containing HRP-labeled cells within HVc were embedded in paraffin and cut into 6- $\mu \mathrm{m}$ sections. The sections were mounted onto glass slides, coated with emulsion, processed for autoradiography to detect $\left[{ }^{3} \mathrm{H}\right]$ thymidine-labeled cells, and counterstained with cresyl violet (for details see Goldman and Nottebohm, 1983). It should be noted that the DAB reaction product produces neither positive nor negative chemography (Trojanowski and Jacobson, 1975) and that [ $\left.{ }^{3} \mathrm{H}\right]$ thymidine autoradiography and HRP biochemistry have been successfully combined to determine the birthdate of neurons with axonal projections in other anatomical systems (Nowakowski et al., 1975 Shaw and Allen 1982; Weber et al., 1984). Thus, these two anatomical methods are compatible.

Neurons in $\mathrm{HV}$ c were counted under a microscope with a $\times 63$ oil objective. Neurons were identified by their clear nucleus, which contains large basophilic nucleoli and which is large relative to the size of the perikaryon. Only cells with a well defined nucleolus within the section were accepted. About $12 \%$ of the neurons of each type examined $\left(\left[{ }^{3} \mathrm{H}\right]\right.$ thymidine labeled, RA projecting, area $X$ projecting) contained more than one nucleolus. Neurons containing HRP were identified by brown deposits of polymerized DAB in the cytoplasm but not the nucleus. Neurons were considered $\left[{ }^{3} \mathrm{H}\right]$ thymidine labeled if the number of grains in the emulsion over the nucleus was at least 10 times that over a comparable area of HVc neuropil. Separate counts were kept of cells containing HRP, radioactive label, or both. Cell counts were corrected for overcounting due to cells cut into adjacent sections (Abercrombie, 1946), and for the presence of multiple nucleoli.

Cell sizes were measured in two animals by tracing camera lucida images of cell bodies on a computer-based planimeter. The reproducibility of these area measurements was $5 \%$. Soma diameters were calculated from measured areas by assuming idealized spherical somas. Samples of about 100 cells of each type were measured in tissue sections from each bird, and their median diameters were compared using a Mann-Whitney $U$-test.

\section{Results}

We wanted to test a hypothesis of "maximum plasticity," namely, that neurons of all kinds are added to adult HVC in their typical proportions. This hypothesis predicts that if, for example, $5 \%$ of all neurons are labeled with $\left[{ }^{3} \mathrm{H}\right]$ thymidine, then $5 \%$ of each type of HVc neuron should also be labeled. In the present experiments two types of HVc cells, those with axons that innervate RA (RA-projecting cells) and those with axons that innervate area X (X-projecting cells), were specifically tested for frequency of $\left[{ }^{3} \mathrm{H}\right]$ thymidine labeling.

The data used to test the hypothesis are shown in Table I. Numbers of cells labeled with HRP, thymidine, or both, and total neurons in sample sections were tallied for each of 10 injections in RA and 13 injections in area $X$. These numbers were obtained with a variety of injection sites within the target nuclei and sections from all positions within HVc. Material was taken from both males and females treated with $\left[{ }^{3} \mathrm{H}\right]$ thymidine during the months from June to February and sacrificed either 30 or 60 days after the last $\left[{ }^{3} \mathrm{H}\right]$ thymidine injection. The expected number of cells labeled with both HRP and $\left[{ }^{3} \mathrm{H}\right]$ thymidine was calculated by multiplying the number of HRP-labeled neurons by the percentage of all neurons labeled by $\left[{ }^{3} \mathrm{H}\right]$ thymidine. These expected numbers were summed over all of the $R A$ injections, and then a separate total was obtained for the area $X$ injections.

Clearly, our initial hypothesis can be rejected. For all RA injections, 692 double-labeled cells were expected and only 12 were seen. For all area $X$ injections, 825 double-labeled cells were expected and only 4 were seen. Both of these differences are highly significant ( $\rho$ $<0.001$ ) using a $\chi^{2}$ test. Furthermore, the hypothesis can be rejected for each individual injection, over a wide range of experimental conditions such as sex, season, and time between thymidine treatment and HRP injection (see the last two columns in Table I).

Methodological considerations suggest that even the few doublelabeled cells found may not all represent projection neurons born in adulthood. First, some of these cells may not have contained any tritium at all. The background level of grains in the autoradiographic emulsion was from 0.5 to 0.6 grains/cell. These grains are randomly distributed according to a Poisson distribution of which the statistics are well known (England and Rogers, 1970). For example, with a background of 0.5 grains/cell, the probability of having five or more grains over any given cell is about 2 in 10,000. This is of the same order as the actual number of double-labeled cells found ( 4 in 10,461 for area $X$ injections; 12 in 7,535 for RA injections).

A second possible problem is that some of the double-labeled cells may have been labeled by HRP which reached the somas directly, and not by retrograde transport from terminals. This is more likely for an injection of HRP into RA because the electrode track passes less than $1 \mathrm{~mm}$ posterior to $\mathrm{HVC}_{\mathrm{C}}$; in our experiments, the single injection with the most widespread distribution of HRP along the track resulted in 7 of the total of 12 double-labeled neurons found in all 10 RA injections (bird 42, left RA in Table I).

A third possibility is that HRP-containing neurons may be closely opposed to thymidine-labeled glia, in such a way that the HRP. containing neuron might be misinterpreted as a doubly labeled cell. This would only affect our tallies where a portion of a glial cell was centered over the nucleus of the HRP-positive neuron.

Despite these potential confounding influences, double-labeled cells with grain densities of many times threshold criteria over the nucleus and well defined DAB reaction product in the surrounding cytoplasm exist, even in animals with clean injections of HRP in area $X$ (see Fig. 1d). Because of this, and in spite of the preceding caveats, we would like to leave open the possibility that some projection neurons are born in adulthood.

Soma sizes were measured to see whether cell size could be used to predict cell type and thereby identify the cell type of $\left[{ }^{3} \mathrm{H}\right]$ thymidine-labeled cells. Distributions of cell sizes for HRP-labeled and $\left[{ }^{3} \mathrm{H}\right]$ thymidine-labeled cells are shown in Figure 2. Several observations can be made. First, the distributions of all three classes of $\mathrm{HV}_{\mathrm{C}}$ neurons (RA projecting, area X projecting, and new neurons) overlap so that identification of cell type by cell size alone is not possible. Second, the median size of $\left[{ }^{3} \mathrm{H}\right]$ thymidine-labeled cells is significantly greater than that of RA-projecting cells, and the median cell size of $\left[{ }^{3} \mathrm{H}\right]$ thymidine-labeled cells is significantly smaller than that of area $X$-projecting cells (using a Mann-Whitney $U$-test; see Table II). Thus, although the size distributions overlap, they are not the sarne; in yerteral, new cells are intermediate in size between the two classes of projecion neurons.

\section{Discussion}

The simplest interpretation of our results is that the new neurons incorporated into $\mathrm{HVC}$ are not projection neurons and, therefore, must be local interneurons. This is consistent with the results of previous intracellular experiments in which none of the sample of $\left[{ }^{3} \mathrm{H}\right]$ thymidine-labeled neurons recorded in $\mathrm{HV}_{\mathrm{c}}$ were projection neurons (Paton and Nottebohm, 1984). However, several points should be noted.

First, how strong is the evidence that the only projections from $H V C$ are to RA or area $X$ ? The original observations were based on silver staining of anterograde degeneration from HVc (Nottebohm et al., 1976). These findings were later confirmed using anterograde transport of HRP from HVc (Nottebohm et al., 1982). More recently, we have used minute injections of the lectin Phaseolus vulgaris agglutinin leucoagglutinin (PHAL; see Gerfen and Sawchenko, 1984) to trace the same projections from HVc. The effective site of PHAL uptake is smaller than that with HRP and, unlike the methods in the aforementioned studies, with immunocytochemistry (the biotin-avidin procedure for immunoperoxidase staining), axons containing PHAL 
TABLE I

Presence within HVC of neurons labeled by $\left[{ }^{3} H\right.$ thymidine, or retrogradely labeled by injection of HRP into either $R A(n=10)$ or nucleus $X(n=13)$

Data have been tabulated for each injection, one per row, and totaled over all RA injections, and over all nucleus $X$ injections. The first five columns of the table contain information on the animals in which the HRP injections were made. The middle three columns data expressed as either the total numbers of cells counted or the percentage of HVc neurons. Maximum percentages in each column are italicized. The last two columns are the expected (see the text for details) and actual numbers of cells doubly labeled with HRP and $\left[{ }^{3} \mathrm{H}\right]$ thymidine.

\begin{tabular}{|c|c|c|c|c|c|c|c|c|c|}
\hline \multirow{2}{*}{ Bird } & \multirow{2}{*}{ Sex } & \multirow{2}{*}{ THYINUN } & \multirow{2}{*}{$\begin{array}{l}\text { Survival } \\
\text { (days) }\end{array}$} & \multirow{2}{*}{ Side } & \multicolumn{2}{|c|}{ HRP CELLS } & \multirow{2}{*}{$\begin{array}{c}{ }^{3} \text { H Cells } \\
(\%)\end{array}$} & \multicolumn{2}{|c|}{ HRP- ${ }^{3} \mathrm{H}$ Cells } \\
\hline & & & & & No. & $\%$ & & Expected & Actua \\
\hline \multicolumn{10}{|c|}{$\mathrm{HRP}$ in $\mathrm{RA}$} \\
\hline & & & & $L$ & 870 & 7.0 & 4.23 & 36.8 & 0 \\
\hline 32 & $f$ & Aug & 30 & $R$ & 740 & 22.0 & 15.0 & 109.6 & 1 \\
\hline 36 & $\mathrm{~m}$ & Oct & 30 & $L$ & 1,111 & 9.4 & 7.71 & 85.6 & 1 \\
\hline & & & & $\mathrm{L}$ & 551 & 9.0 & 15.0 & 81.2 & 7 \\
\hline 45 & $f$ & Feb & 60 & L & 786 & 12.1 & 13.6 & 107.1 & 1 \\
\hline \multirow[t]{2}{*}{46} & $t$ & Feb. & 60 & $\mathrm{R}$ & 622 & 7.7 & 9.4 & 58.4 & 0 \\
\hline & & & & L & 473 & 12.5 & 9.77 & 46.2 & 0 \\
\hline Totals & & & & & 7,535 & & & 691.7 & 12 \\
\hline \multicolumn{10}{|l|}{ HRP in $X$} \\
\hline \multirow[t]{2}{*}{37} & $f$ & Oct & 30 & $\mathrm{R}$ & 29 & 13.6 & 16.1 & 4.7 & 0 \\
\hline & & & & $\mathrm{L}$ & 23 & 11.3 & 17.1 & 3.9 & 0 \\
\hline \multirow[t]{2}{*}{38} & $\mathrm{~m}$ & Oct & 30 & $\mathrm{R}$ & 799 & 6.9 & 6.4 & 51.2 & 0 \\
\hline & & & & $\mathrm{L}$ & 321 & 16.1 & 7.07 & 22.7 & 0 \\
\hline \multirow[t]{2}{*}{39} & $f$ & Nov & 30 & $\mathrm{R}$ & 803 & 17.7 & 15.8 & 127.0 & 1 \\
\hline & & & & $\mathrm{L}$ & 198 & 10.7 & 16.1 & 31.9 & 0 \\
\hline \multirow[t]{2}{*}{43} & $f$ & Feb & 60 & $\mathrm{R}$ & 656 & 11.9 & 11.9 & 78.0 & 0 \\
\hline & & & & $\mathrm{L}$ & 895 & 20.0 & 14.0 & 125.3 & 0 \\
\hline 44 & $\mathrm{~m}$ & Feb & 60 & $\mathrm{~L}$ & 1,076 & 15.8 & 5.43 & 58.4 & 0 \\
\hline Totals & & & & & 10,461 & & & 824.5 & 4 \\
\hline
\end{tabular}

are completely stained in a Golgi-like fashion. With the PHAL method axons could be traced from HVc to RA and from HVc to area $X$, and a few fibers were labeled in the hyperstriatum anterior to HVC, with no apparent target. This third set of axons labeled with PHAL may be fibers passing through or near HVc such as those from locus ceruleus (J. A. Paton and G. D. Burd, unpublished observation); but in any case it is not large enough to account for the entire population of new neurons in HVc. Thus, experiments with three different methods agree that $H V_{C}$ has strong projections to RA and area $X$ and provide no evidence of other major projections.

Second, it is possible that some neurons in HVc send axons to $\mathrm{RA}$ or area $X$ but that these cells were not retrogradely filled. To avoid any bias in our sampling of cells or in our protocol for detecting HRP, we have varied a number of experimental parameters, e.g., injection site, position within $H V_{c}$, sex, season, and survival time after HRP injection. The same results were obtained for each injection. Even if the axon terminals of all types of projection neurons had access to HRP, the somas might not have been labeled. Pathways which apparently did not transport HRP have been reported (e.g., Nauta et al., 1974); however, these results have usually been reversed by using more sensitive procedures, such as the present $\mathrm{DAB}$ method, to detect HRP.

Third, it might be argued that axons of newly formed cells may not have reached RA or area $X$ in the time allowed. In previous intracellular experiments we have shown that, 30 days after the last of a 14-day series of $\left[{ }^{3} \mathrm{H}\right]$ thymidine injections, radioactively labeled HVc neurons have well differentiated dendritic and axonal arbors, and some have been recruited into existing networks, as shown by their response to acoustic stimuli (Paton and Nottebohm, 1984). In the present study, birds were killed either 30 or 60 days after the last $\left[{ }^{3} \mathrm{H}\right]$ thymidine injection, allowing as much or more time for the new neurons to form their afferent and efferent connections. Another argument is based on known rates of axonal elongation. To be incorporated into existing neural circuitry, new cells must migrate from the ventricular zone into HVc (Goldman and Nottebohm, 1983), differentiate into neurons, and extend axons to their normal targets. From previous work we know that thymidine-labeled neurons can be seen in $\mathrm{HVC}$ as early as 15 days after the onset of $\left[{ }^{3} \mathrm{H}\right]$ thymidine treatment ( $F$. Nottebohm, unpublished observation). A conservative estimate of axonal growth in vivo would be approximately $10 \mu \mathrm{m} / \mathrm{hr}$ (see Jacobson, 1978, pp. 131-132). At this rate, axons should extend the $4 \mathrm{~mm}$ from HVc to area $X$ in another 16 days, for a total of 31 days from neurogenesis to full axonal elongation. In our experiments, either 44 or 74 days elapsed between the initial thymidine injection and the HRP injections, allowing the new neurons more than enough lime lo form connections.

There are precedents for the suggestion that neurons born late in development or even in adulthood are interneurons. Altman (1970) noted that in all cases known to him involving late developing structures, such as cerebellum, hippocampus, and olfactory bulb, the newly recruited neurons were microneurons that acted as local interneurons. More recent observations consistent with this pattern have been catalogued by Jacobson (1978, pp. 58-60). Our findings agree with these previous cases, with the exception that the cells we have tentatively identified as interneurons are not the smallest neurons present. 

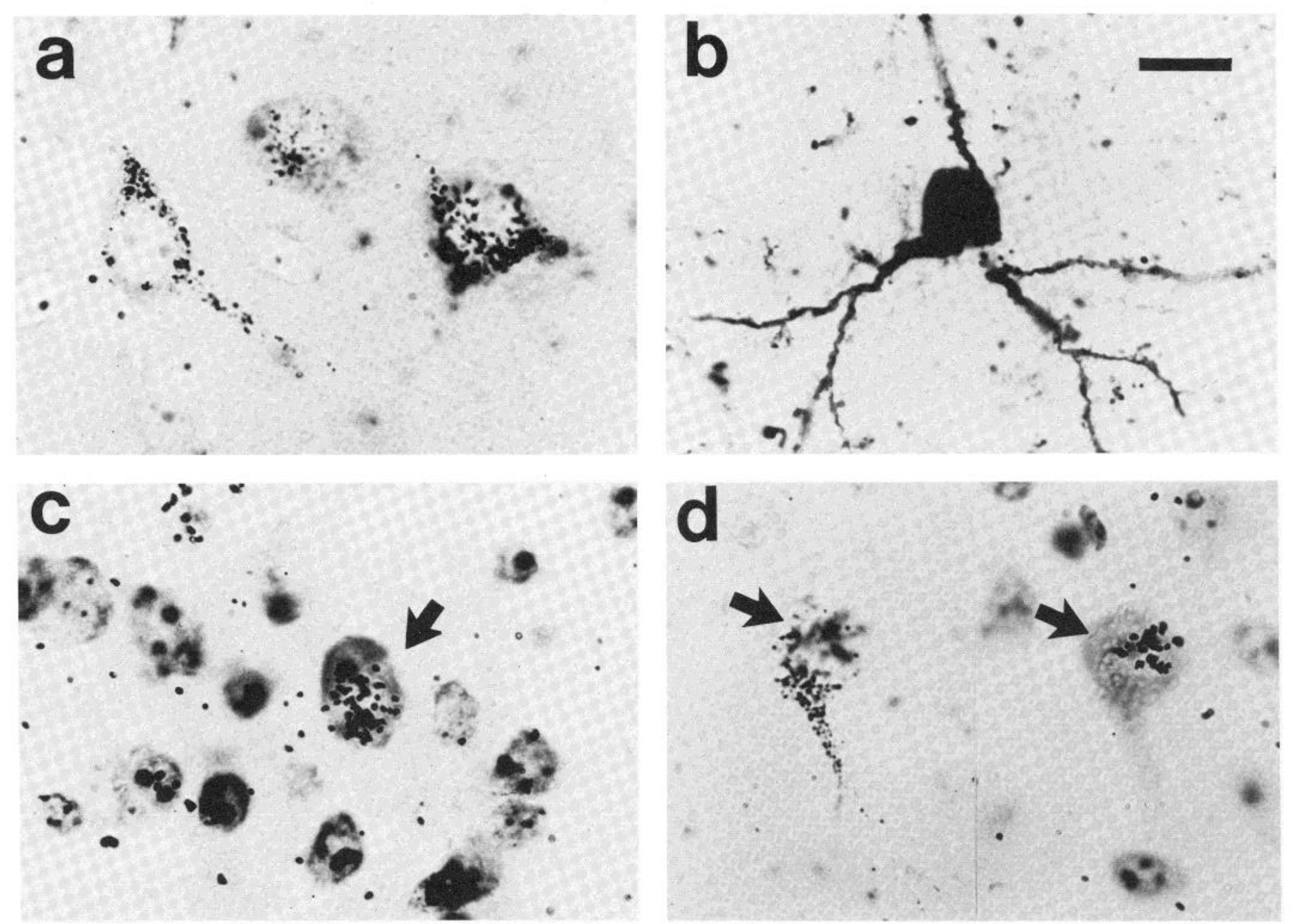

Figure 1. Examples of the types of HVc neurons examined in this study. The calibration marker in $b$ represents $10 \mu \mathrm{m}$ for all parts of this figure. $a$, Area $X$-projecting neurons, labeled by HRP retrogradely transported from area X. The DAB reaction product is granular and restricted to the cytoplasm. $b$, RAprojecting neuron, heavily labeled by HRP retrogradely transported from nucleus RA. The DAB reaction product is uniformly distributed within the cytoplasm. $c$, New neuron, with multiple silver grains in the layer of emulsion over its nucleus. This cell was labeled by treating an adult bird with $\left[{ }^{3} \mathrm{H}\right]$ thymidine. $d$, Doubly labeled neuron. The photograph on the left is focused on the DAB granules within the cytoplasm of the cell and was taken with a no. 46 blue Wratten filter. The photograph on the right shows the grains in the emulsion over the nucleus of the same cell.

If interneurons are the only cells added to $\mathrm{HVc}$, the previous estimates of rates of cell addition within this subset of HVc neurons will have to be increased. The distributions of cell sizes in our experiment and the results of double retrograde label experiments (Bonafede, 1984) both suggest that separate sets of projection neurons innervate RA and area X. In our best cases of retrograde labeling, $22 \%$ of the cells in HVc projected to RA and $23 \%$ of the cells in HVc projected to area X (see italicized numbers in Table I). Thus, at least $45 \%$ of the neurons in HVc are projection neurons. The remaining $55 \%$ of the cells in HVc could be interneurons and possibly new neurons. In other words, within the pool of interneurons, not $1.5 \%$ but $3 \%$ of the cells would be labeled per day of $\left[{ }^{3} \mathrm{H}\right]$ thymidine treatment, or almost $100 \%$ per month. Even this is a conservative estimate, for the new neurons may only represent a subset of all interneurons.

There is some evidence that this mass of new neurons is not simply migrating through HVc. In previous intracellular experiments, new neurons were found which had fully differentiated axonal and dendritic processes, received synaptic input, and supported action potentials. Thus, new neurons appear to be incorporated into the existing neuronal circuitry. Based on this, and the fact that the number of neurons in HVc does not appear to increase from year to year, Nottebohm (1984) has hypothesized that the new neurons replace other neurons.

The addition of interneurons rather than projection neurons should limit the ability of the adult brain to recover from injury. For example, if projection neurons or their axons were damaged, adding or generating new interneurons alone would seem to be of limited usefulness. However, there is now evidence from other laboratories that brain damage can alter the environment and the connections of transplanted cells. Denervating potential targets for new cells increases the density of innervation markedly (Bjorklund and Stenevi, 1979), and neuronotrophic factors have been found at lesion sites (Nieto-Sampedro et al., 1982). Thus, it seems reasonable to ask whether lesions to $\mathrm{HVC}$ or its output fibers might lead to the generation of more projection neurons than we have found in the intact brain.

Our results also have implications for the development of circuitry in the intact central nervous system. If projection neurons are not normally produced in adulthood, then they must be produced earlier. One might imagine the projection neurons as forming a relatively permanent scaffolding on which interneurons are later added. In this scheme, the continuing addition of interneurons to the adult brain could dramatically remodel the way in which neuronal activity is 
(A)
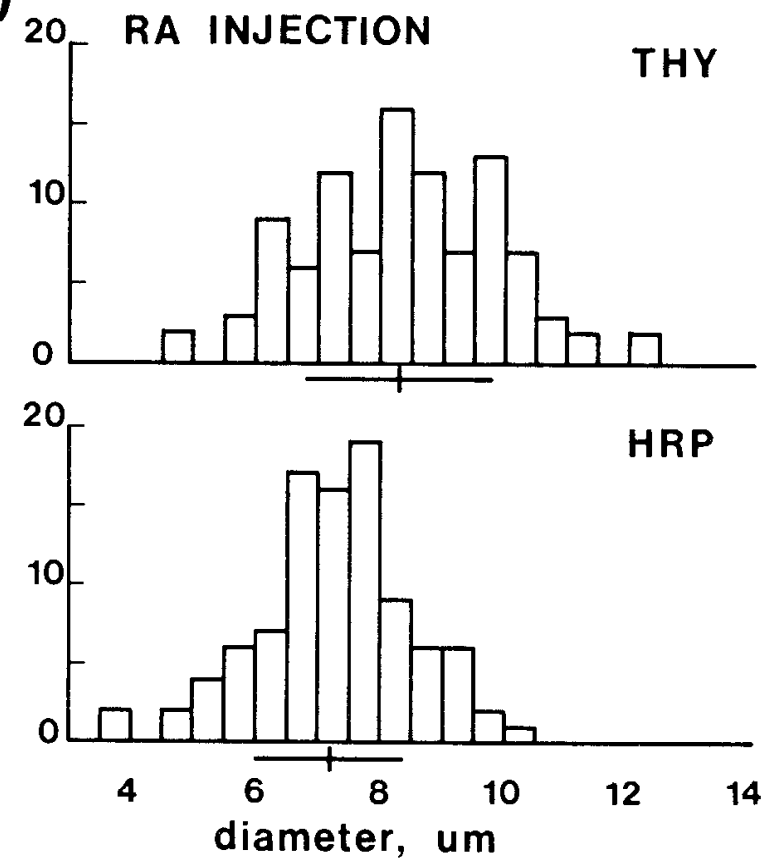

(B)
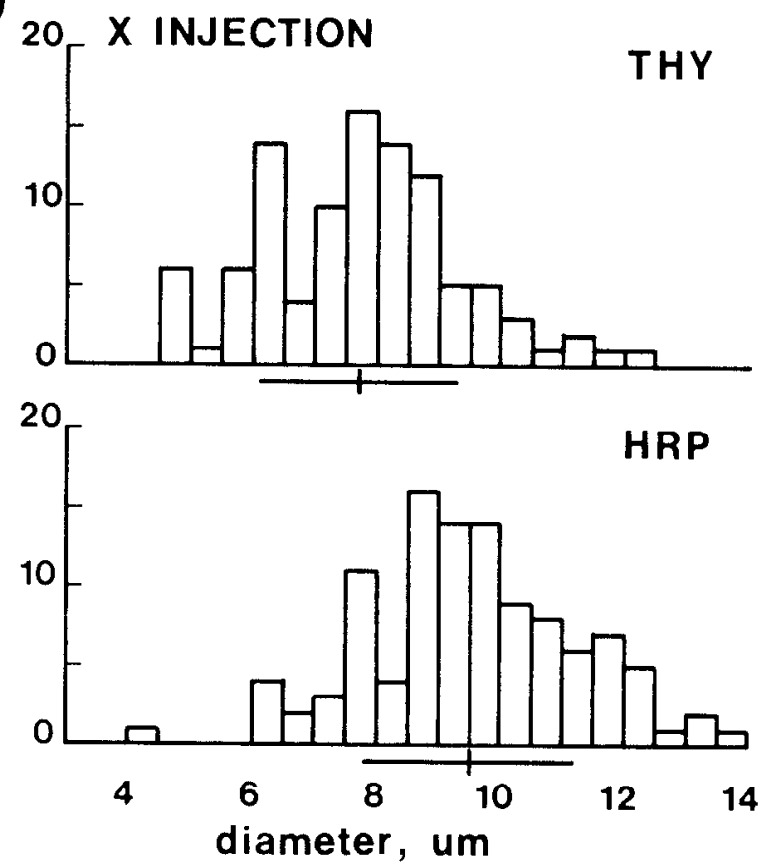

Figure 2. Distribution of soma sizes for the three types of HVc neurons examined. Samples of about 100 cells of each type were taken from two different male canaries. A, Comparison of soma diameters measured in the same sections of tissue for RA-projecting neurons versus [ $\left.{ }^{3} \mathrm{H}\right]$ thymidine-labeled neurons. $B$. Comparison of the soma diameters measured in the same sections of tissue of area X-projecting neurons versus [ ${ }^{3} \mathrm{H}$ ]thymidine-labeled neurons. Mean diameters and standard deviation bars are shown below each distribution.

TABLE ॥

Statistical comparison of the soma diameters of projection neurons and $[$ H] thymidine-labeled neurons

The projection neurons were labeled by injecting HRP into either RA (row 1 or nucleus $X$ (row 2). These statistics are derived from the same sample of cells used in Figure 2. Means and standard deviations are given as measures of the location and spread of the distributions of some diameters. Differencess in the median soma diameters were separately calculated using the Mann-Whitney $U$ test, a nonparametric analysis.

\begin{tabular}{|c|c|c|c|c|c|c|c|}
\hline & \multicolumn{3}{|c|}{${ }^{3} \mathrm{H}$-labeled } & \multicolumn{3}{|c|}{ HRP-labeled } & \multirow{2}{*}{$\begin{array}{c}\text { Significance } \\
\text { ( } U \text { test) }\end{array}$} \\
\hline & $n$ & Mean & $\mathrm{SD}$ & $n$ & Mean & $\mathrm{SD}$ & \\
\hline HRP in RA & 97 & 8.30 & 1.54 & 101 & 7.21 & 1.23 & $<0.001$ \\
\hline HRP in $X$ & 101 & 7.69 & 1.61 & 108 & 9.48 & 1.73 & $<0.001$ \\
\hline
\end{tabular}

processed as it passes through HVC. It is our hope that, as we learn more about the natural history of neurogenesis and the connectivity of new neurons, it may be possible to test this hypothesis.

\section{References}

Abercrombie, M. (1946) Estimation of nuclear population from microtome sections. Anat. Rec. 94: 239-247.

Altmani, J. (1970) Posinalal neurogenesis and the problem of neural plasticity. In Developmental Neurobiology, W. A. Himwich, ed., pp. 192-237, Charles C Thomas, Springfield, IL.

Bayer, S. A. (1983 $)^{3} \mathrm{H}$-Thymidine-radiographic studies of neurogenesis in the rat olfactory bulb. Exp. Brain Res. 50: 329-340

Bayer, S. A., J. W. Yackel, and P. S. Puri (1982) Neurons in the rat dentate gyrus granular layer substantially increase during juvenile and adult life. Science 216: 890-892.

Bjorklund, A., and (J. H. Stenevi (1979) Reconstruction of brain circuitries by neural transplants. Trends Neurosci. 2: 301-306.

Bonafede, D. M. (1984) In vitro morphological study of identified neurons in nucleus HVC of the zebra finch (Pocphila guttata) and of the Bengalese finch (Lonchura striata) song system. B.S. Thesis, California Institute of Technology, Pasadena.

Burd, G. D., and F. Nottebolnm (1985) Ullrastructural characterization of synaptic terminals formed on newly generated nerons in a song control nucleus of adult canary forebrain. J. Comp. Neurol, in press.
Easter, S. S. (1983) Postnatal neurogenesis and changing connections. Trends Neurosci. 6: 53-56.

England, J. M., and A. W. Rogers (1970) The statistical analysis of autoradiographs. I. Grain count distributions over uniformly labeled sources. J. Microsc. 92: 159-165

Fujita, S. (1966) Application of light and electron microscopic autoragiography to the study of cytogenesis of the forebrain. In Evolution of the Forebrain. Phylogenesis and Ontogenesis of the Forebrain, R. Hassler and $\mathrm{H}$. Stephan, eds., pp. 180-196, Thierne, Slullyart.

Gerfen, C. R., and P. E. Sawchenko (1984) An anterograde neuroanatomical tracing method that shows the detailed morphology of neurons, their axons and terminals: Immunohistochemical localization of an axonally transported plant lectin, Phaseolus vulgaris leucoagglutinin (PHAL). Brain Res. 290: 219-238.

Goldman, S. A., and F. Nottebohm (1983) Neuronal production, migration and differentiation in a vocal control nucleus of the adult female canary brain. Proc. Natl. Acad. Sci. U. S. A. 80: 2390-2394.

Jacobson, M. (1978) Developmental Neurobiology, Ed. 2, Plenum Press, New York.

Kaplan M. S. (1981) Neurogenesis in the 3-month-old rat visual cortex. J. Comp. Neurol. 195: 323-338

Kaplan, M. S., and D. H. Bell (1983) Neuronal proliferation in the 9-month-old rodent-Radioautographic study of granule cells in the hippocampus. Exp. Brain Res. 52: 1-5.

Kaplan, M. S., and D. H. Bell (1984) Mitotic neuroblasts in the 9-day-old and 11-month-old rodent hippocampus. J. Neurosci. 4: 1429-1441.

Kaplan, M. S., and J. W. Hinds (1977) Neurogenesis in the adult rat: Electron microscopic analysis of light radioautographs. Science 197: 1092-1094.

Korr, H. (1980) Proliferation of different cell types in the brain. Adv. Anat. Embryol. Cell. Biol. 61: 1-72.

Leonard, R. B., R. E. Coggeshall, and W. D. Willis (1978) A documentation of an age-related increase in neuronal and axonal numbers in the stingray, Dasyatis sabine, Leseur. J. Comp. Neurol. 179: 13-21.

Luine, V., F. Nottebohm, C. Harding, and B. McEwen (1980) Androgen affects cholinergic enzymes in songbird syringeal motor-neurons and muscle. Brain Res. 192: 89-107.

Malmgren, L., and Y. Olsson (1978) A sensitive method for histochemical demonstration of horseradish peroxidase in neurons following retrograde axonal transport. Brain Res. 148: 279-294.

Nauta, H. J. W., M. B. Pritz, and R. J. Lasek (1974) Afferents to the rat caudoputamen studied with horseradish peroxidase. An evaluation of a retrograde neuroanatomical research method. Brain Res. 67: 219-238. 
Nieto-Sampedro, M., E. R. Lewis, C. W. Cotman, M. Manthorpe, S. D. Skaper, G. Barbin, F. M. Longo, and S. Varon (1982) Brain injury causes a timedependent increase in neuronotrophic activity at the lesion site. Science 217: 860-861.

Nottebohm, F. (1980) Testosterone triggers growth of brain vocal control nuclei in adult female canaries. Brain Res. 189: 429-436.

Nottebohm, F. (1984) Birdsong as a model in which to study brain processes related to learning. The Condor $86: 227-236$

Nottebohm, F., and S. A. Goldman (1982) Connectivity and kinetics of neurons born in adulthood. Soc. Neurosci. Abstr. 8: 140.

Nottebohm, F., T. M. Stokes, and C. M. Leonard (1976) Central control of song in the canary, Serinus canarius. J. Comp. Neurol. 165: 457-486.

Nottebohm, F., D. B. Kelley, and J. A. Paton (1982) Connections of vocal control nuclei in the canary telencephalon. J. Comp. Neurol. 207: 344357.

Nowakowski, R. S., J. H. LaVail, and P. Rakic (1975) The correlation of the time of origin of neurons with their axonal projection: The combined use of ${ }^{3} \mathrm{H}$-thymidine autoradiography and horseradish peroxidase histochemistry. Brain Res. 99: 343-348.

Paton, J. A., and K. Manogue (1982) Bilateral interactions within the vocal control pathway of birds: Two contrasting strategies. J. Comp. Neurol. 212: 329-335.
Paton, J. A., and F. Nottebohm (1984) Neurons generated in the adult brain are recruited into functional circuits. Science 225: 1046-1048.

Shaw, M. D. and K. E. Allen (1981) Generation of the oculomotor nuclei and their cell types in the rabbit. J. Comp. Neurol. 200:69-82.

Sidman, R. (1970) Autoradiographic methods and principles for study of the nervous system with thymidine- $\mathrm{H}^{3}$. In Contemporary Research Methods in Neuroanatomy, W. Nauta and S. Ebbesson, eds., pp. 252-274, SpringerVerlag, Berlin.

Sidman, R. L., L. L. Miale, and N. Feder (1959) Cell proliferation and migration in the primitive ependymal zone: An autoradiographic study of histogenesis in the nervous system. Exp. Neurol. 1: 322-333.

Stokes. T. M. . C. M. Leonard, and F. Nottebohm (1974) The telencephalon, diencephalon, and mesencephalon of the canary, Serinus canaria, in the stereotaxic coordinates. J. Comp. Neurol. 156: 317-374.

Trojanowski, J. Q., and S. A. Jacobson (1975) A combined horseradish peroxidase/autoradiographic investigation of reciprocal connections between superior temporal gyrus and pulvinar in squirrel monkey. Brain Res. 85: $347-353$

Weber, A. J., T. L. Hickey, and R. E. Kalil (1984) Genesis of interneurons in the dorsal lateral geniculate nucleus (LGN) of the cat. Invest. Opthalmol. Vis. Sci. Suppl. 25: 125. 